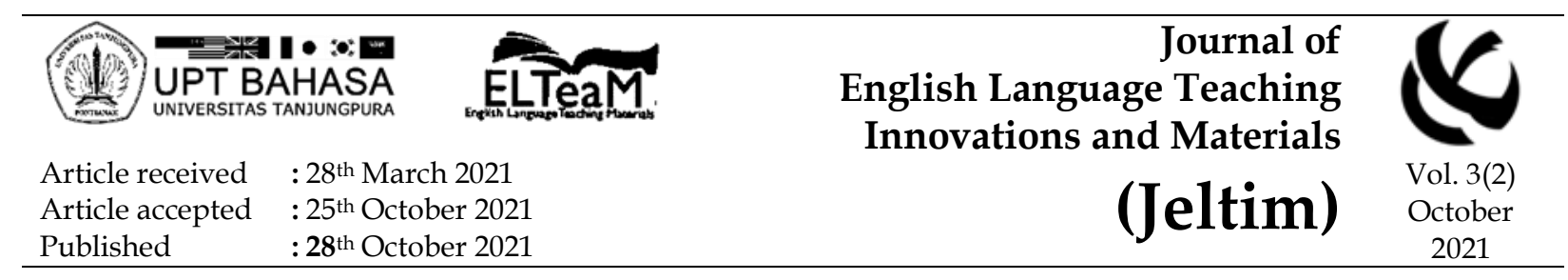

\title{
Forensic digest: the discourse on heinous crimes in Mindanao Court of Appeals
}

\author{
Grace S. Rafal \\ English Department, College of Social Sciences and Humanities, Mindanao State \\ University, Marawi City, Lanao del Sur, Mindanao, Philippines \\ grace.rafal@msumain.edu.ph
}

DOI: http://dx.doi.org/10.26418/jeltim.v3i2.45430

\begin{abstract}
This study investigated the discourse of the Court of Appeals (CA) in Mindanao, Philippines. It examined the court decisions reversely decided in the Fiscal Year 2013 on heinous crimes filed in the Court of Appeals. This research focused on the different rhetorical and discursive devices employed in the court decisions and examined how these devices performed in the production of the text to grant the appellant's request on the reversal of the decision in the case. It scrutinized the ideological themes in the reversed decisions through the lenses of Critical Discourse Analysis and Rhetorical Analysis. The different rhetorical devices employed in the court decisions are organized into preeminent rhetorical devices, or devices most often used in the court decisions, and peripheral rhetorical devices, or those minimally used. The Preeminent Rhetorical Devices are double speak, slanting, ambiguity, aphorism, repetition, subordinate clause / delayed sentence, periodic sentence, passivization, and active voice. The Peripheral Rhetorical Devices are weaselers, aporia, and hypophora. The discursive devices employed in the production of the Court Decisions are scenesetting, specificity /indirect quotes, blame, consensus/ collaboration, premodifiers, extreme case formulations, and disclaimers. The ideological themes manifested in the specimens are the power asymmetry and just to cast the blame by the victim or the family of the victim and by the law enforcers. under power asymmetry are unsound judgment among trial or lower courts, abuse of power by the trial or lower court and by the law enforcers or arresting officers, and poor as victims of injustices. The following generated postulates are: pre-arranged signal: a non-verbal forensic discourse; Rule on chain of custody: the mantra of the drug crime discourse; Extrajudicial oral confessions discourse; and the charge and solve discourse.
\end{abstract}

Journal of English Language Teaching Innovations and Materials (Jeltim), 3(2), 109-130

Copyright () 2021 by the author, e-ISSN 2657-1617 
Keywords: forensic; discourse; heinous crimes; appeals, CDA

How to cite this paper: Rafal, G. (2021). Forensic digest: the discourse on heinous crimes in Mindanao Court of Appeals. Journal of English Language Teaching Innovations and Materials (Jeltim), 3(2), 109-130. DOI: http:/ / dx.doi.org/10.26418/jeltim.v3i2.45430

To link to this article: http:/ / dx.doi.org/10.26418/jeltim.v3i2.45430

This work is licensed under a Creative Commons Attribution NonCommercial-ShareAlike 4.0 International License.

Language is power and behind the language is power. Succinctly laid, the tenets of different discursive connoisseurs set forth this idea to explain how powerful language is used sturdily by powerful personages to advance their own hegemonic agenda (Fairclough, 1995). Accordingly, that behavior causes incongruence, disparities, and inequalities among supposed stakeholders in certain discursive contexts. Inspired by that knowledge, this current endeavor is furthered by the researcher, whose focus of study is on the legal discourse in the Court of Appeals in Mindanao, specifically on the discourse on heinous crimes within rulings reversed on appeal by the Court of Appeals in Mindanao during Fiscal Year 2013 through the Court's Decisions.

In line with the foregoing, the researcher scrutinized the power relations between and among the stakeholders of the Court of Appeals in Mindanao by examining the Court Decisions about heinous crimes reversed on appeal by CAMindanao, which means that the decisions of the lower or trial courts were set aside; thus, the defendants convicted in the lower courts who appealed in the Court of Appeals in Mindanao were acquitted of their sentences or convictions and set free from guilt.

The Court decisions reversed on appeal that involved heinous crimes were analyzed as a myriad of representations of the voices of the appellants seeking reversal of the decisions in the lower courts. They represented the voices of the ones asking for dismissal of their appeals and to keep the decision of the lower court to convict the accused. They also represented the voices of the unheard in the lower court, which were the different testimonies that were not given importance by the lower court. The court decisions also represented the voice of the higher court, which is the Court of Appeals in Mindanao to provide a check and balance on the different forms of evidence furnished to them by the appellants and the appellees. The higher court would decide if the accused in the lower courts were to be convicted beyond reasonable doubt of the heinous crimes they committed or "the accused-appellants would be acquitted from the crime which does not necessarily mean that they were in truth not the perpetrators, but

Journal of English Language Teaching Innovations and Materials (Jeltim), 3(2), 109-130

Copyright (C) 2021 by the author, e-ISSN 2657-1617 
the only basis for the acquittal is reasonable doubt, which simply means that the prosecution's evidence is insufficient to convict them" (The People of the Philippines, Plaintiff-Appellee, - Versus - CletoTejero, Accused-Appellant, 2013).

Wodak (in Hyland 2011) defined discourse as an analytical category describing the vast array of meaning-making resources available to everybody. Discourse is socially constitutive and socially shaped: it constitutes situations, objects of knowledge and the social identities of and relationships between people and groups of people. It is constitutive both in the sense that it helps sustain and reproduce the social status quo, and in the sense that it contributes to transforming it. According to Foucault and Derrida, language and discourse are not transparent or neutral means for describing or analyzing the social and biological world. Rather they effectively construct, regulate and control knowledge, social relations, and institutions. Subsequently, those terms begot critical discourse analysis that begins from recognition of language and discourse as non-transparent, opaque ways of studying and representing the world. It assumes that systematic asymmetries of power and resources between speakers and listeners, readers and writers can be linked to their unequal access to linguistic and social resources (http://en.Critical_discourse_analysis).

In agreement to Olsson (in Hyland, 2011), discourse analysis exists in several varieties, including 'forensic'. Previously, forensic discourse was on police interaction with suspects and defendants. But later, it came to include court examination and cross-examination, language use in lawyer-client relationships and the analysis of a variety of text types. These are forensic texts, which are any texts or items used in a legal or criminal context, to include analyzing documents such as Acts of Parliament (or other law-making body), private wills, court judgments, summonses, and the statutes of other bodies (http://Forensic_linguistics). Studying these forensic texts made more lawyers and judges realize the potential value to the legal profession and the need for cross-discipline cooperation to become more extensive, to reduce abuses and ensure that the legal systems can live up to their frequent claims of due process, impartiality and universal fairness (Olsson in Hyland, 2011).

When someone is arrested for a crime, it is the beginning of a long journey through the criminal justice system until the case is resolved. Some cases end quickly with a guilty plea and paying a fine. Others can go on for decades through the appeals process because everyone accused of a crime is assumed innocent until proven guilty in a court of law. Even if someone cannot afford to hire a lawyer, s/ he has the right to a fair trial. The criminal justice system is there to protect the innocent and seek the truth. But there are many cases in which individuals are arrested, sentenced, and convicted of crimes they have not done, or they are given an unfair sentence or penalty. Consequently, they must go to

Journal of English Language Teaching Innovations and Materials (Jeltim), 3(2), 109-130

Copyright (C) 2021 by the author, e-ISSN 2657-1617 
the appellate court, or they must appeal their cases to the higher courts to seek justice for their cases.

\section{METHOD}

There were thousands of cases involving heinous crimes decided in FY 2013 in the Mindanao Court of Appeals, but there were only twenty-two (22) such cases acquitted or reversed for heinous crimes which are rape, carnapping with homicide, parricide, murder, and drugs or violation of Sec 5, Art 2 of RA 9165, otherwise known as the Comprehensive Dangerous Drugs Act of 2002.

Of the twenty-two (22) cases, this research analyzed twelve (12) court decisions for the twelve (12) cases. This study used purposive sampling for parricide and carnapping with homicide since there was only one case of each of these types of heinous crimes. Of the two (2) rape cases, this study chose the multiple rape case as a specimen. This study analyzed three (3) of the five (5) murder cases, and twelve (12) drug-related cases, of which this research randomly sampled six (6). For the last two (2) categories, a lottery was used. The twelve (12) court decisions for the twelve (12) cases as the specimens of this study were gathered from www.ca.judiciary.gov.ph, the website of the Court of Appeals in Mindanao.

\section{FINDINGS AND DISCUSSIONS}

\section{Rhetorical devices and their roles}

The different rhetorical devices employed in the court decisions of the heinous crime cases reversed on appeal in the FY 2013 of the Court of Appeals in Mindanao are organized into Preeminent Rhetorical Devices, or frequently used in the court decisions, and Peripheral Rhetorical Devices, or minimally used. The following are the Preeminent Rhetorical Devices; double speak, slanting, ambiguity, aphorism, repetition, subordinate clause / delayed sentence, periodic sentence, passivization, and active voice. The Peripheral Rhetorical Devices are the weaselers, aporia, and hypophora.

\section{Preeminent Rhetorical Devices}

\section{Double Speak}

Double speak is the substitution or invention of terms either for favorable overtones or negative bias. It includes euphemism and dysphemism (Alonto, et. $\mathrm{Al}, 2014)$. The Court Decisions employed only euphemism.

\section{Euphemism}

Euphemism is a substitution or invention of terms having favorable or positive meaning or association, or at least neutral overtones, for unfavorable

\footnotetext{
Journal of English Language Teaching Innovations and Materials (Jeltim), 3(2), 109-130

Copyright (C) 2021 by the author, e-ISSN 2657-1617
} 
terms, for example, "senior" for old, "freedom fighters" for terrorists, "intelligence agent" for spy, "unacceptable borrowing" for plagiarism, etc. (Alonto, et. Al, 2014). It is a substitution of an agreeable or at least non-offensive expression for one whose plainer meaning might be harsh or unpleasant (http:/ / facstaff.bloomu.edu/jtomlins/rhetorical_devices.htm;

http://www.virtualsalt.com/rhetoric.htm). The court decisions have employed the following euphemisms:

1. carnal knowledge or 2. abused for the word rape

... did then and there willfully, unlawfully and feloniously take turns in having carnal knowledge of AAA ** against her will....

COURT: you said in the previous hearing that you were already abused before you were boxed and you lost consciousness, but in your statement, you said that you were boxed and then you lost consciousness. You did not mention whether you were already abused or not. You clarify, were you already abused before you lost consciousness or were you abused after having been boxed and lost consciousness?

\section{Academic for dead}

The prosecution opposed the motion arguing that the issue had already been rendered moot and academic because the trial court had already discharged Bueta as state witness.

\section{4. acted in concert for conspired}

WHEREFORE, the Court finds the accused $x x x$, having conspired or acted in concert, in committing the crime of Carnapping with Homicide, in taking away the motorcycle.

\section{Claimed the life for killed}

But, their sleep was short lived when police officers detailed in Police Outpost Tugbok Community came to invite Solomon to the police station because of a shooting incident that claimed the life of Thelma.

6. cannot turn a blind eye for ignore

This Court cannot turn a blind eye to the evident irregularities that are present in the case at bar.

The different trial or lower courts used at least neutral overtones for unfavorable terms, but these terms create within the audience a sense of emotion like outrage, anger, etc. Though expressions such as carnal knowledge or abused for the word rape, academic to mean dead, acted in concert for conspired, claimed 
the life for killed are quite pleasant to hear, yet they evoke atrocities to the audience upon reading the context of the discourse. These give the readers deeper drama on the consummation of the activity being done. With the use of the euphemisms, the social contexts, the beliefs, the emotions and ideologies of the speakers or communicators were revealed; the trial courts in this case believed that the accused were the ones who took carnal knowledge, who acted in concert, who killed the victim through the splashing of the blood that claimed the lives of the victims.

The Appellate Court or the reviewing Court, the Mindanao Court of Appeals used the following euphemistic words well under custodial investigation for coercive investigation, glossed over for focused on, aftermath for after the incident, holds water for meritorious or has merits, and cannot turn a blind eye for ignore. Those terms are convivial and quite pleasant words; however, taking a closer look at them would make one realize what wrong the trial courts did in such a way that the reviewing court did not confirm the lower courts' decisions. Instead, the former set aside and reversed the decisions, acquitted the accusedappellants, and ordered the immediate release from custody or confinement or detention of the accused-appellants. Those terms give avenue to the Court of Appeals in Mindanao in reversing decisions in the appealed cases. The Court of Appeals cannot turn a blind eye on the evident irregularities that were present and on the evidence that holds water. Some of those evidence were the accusedappellants suffered from police brutality through coercive or forceful investigation in which the accused were mauled, boxed and framed-up. There were cases in which the trial courts only glossed over, emphasized, or focused only on the infirmity or incredulity of the appellant's defense of alibi and denial. They only focused on circumstantial evidence like seeing the appellant outside the house of the victim in the aftermath of the shooting, and/or the trial courts did not give importance to the other elements for the decision of the case. Thus, the euphemistic devices give the leeway to the Court of Appeals in asserting their decisions in granting the appellants the acquittal of their cases.

In the study of Selda Unvar and Ali Rahimi (2013) entitled "A Critical Discourse Analysis of Discursive Structures in a Political Text", in which euphemism was used by President Obama on his Victory speech, the researchers said that language can be a tool at the hands of speakers or writers for publicity, advertisement, persuasion and creation of the necessary dazzling charisma. In this study, they found out that the discursive structures in Obama's Victory Speech are manifested in his utilization of linguistic techniques of euphemization. His efforts to create the feelings of euphoria, felicity, excitement, glorified patriotism, enormous success are linguistically manifested in his appeal to psychological procedures of self and national glorification through euphemization. The same with the current study that language is a tool of the different trial courts to argue on their decisions of convicting the accused

Journal of English Language Teaching Innovations and Materials (Jeltim), 3(2), 109-130

Copyright (c) 2021 by the author, e-ISSN 2657-1617 
and a tool for the reviewing court to dispute that the trial courts erred in their decisions, hence, the accused appellants would be acquitted and the decisions of the trial or lower courts would be set aside and reversed, consequently, the accused appellants would be released from detention.

\section{Slanting}

Slanting is making a true statement to imply or suggest something which is either false or not known to be true. It is using suggestive power of words and phrases to convey and evoke favorable and unfavorable images (Alonto, et. Al, 2014). The following are some of the false or not known to be true statements which are implied in statements that seem to be true, which are found in the court decisions.

The prosecution opposed the motion arguing that the issue had already been rendered moot and academic because the trial court had already discharged Bueta as state witness.

The case was not moot and academic because according to Black (1983), "an action is considered 'moot' when it no longer presents a justiciable controversy because issues involved have become Academic or Dead. The case in which the matter in dispute has already been resolved and hence, one not entitled to judicial intervention unless the issue is a recurring one and likely to be raised again between the parties." In fact, the issue was a recurring one and the case had been raised again between the parties, thus it is not true that the case was moot and academic. Thus, the prosecution on the rape case was making a true statement that implies or suggests something which is false.

The trial court granted Bueta's motion, ruling that "[t]he discharge and consequent acquittal of Bueta became irrevocable upon his testifying against his co-accused in accordance with his own statement.

Since the case is still going on then, nothing yet is irrevocable. The trial court knows that the case could be brought to the higher court, so the irrevocability is impossible; consequently, that statement is not true. It is a slanting statement.

Although appellant claimed that he was only forced by the police operatives to admit the crime, such claim becomes insignificant in light of the failure of both appellants to file any criminal, civil, or administrative case against the police operatives who committed the alleged forcible extraction of admission or confession.

Case law teaches that much weight is to be given to the testimony of the operative[s], who are presumed to have performed duties in a regular manner.

Journal of English Language Teaching Innovations and Materials (Jeltim), 3(2), 109-130

Copyright (C) 2021 by the author, e-ISSN 2657-1617 
How did they perform their duty if they tortured their detainees? Like this:

Q: After the police told you that you are the suspect what did you do, if there's any?

A: They forced me to confess the truth, and afterwards they mauled me. And after that they brought me to the Police Station.

Even if it is clear in the above cross-examination that the accused was only forced by the arresting officers, the trial court still said that the police officer performed his duty in a regular manner. So that statement is not true. The trial court must know that it is not true that the failure of the accused to file criminal and civil cases against the police operatives for forcing them to admit the crime would mean that the claim of the accused on forcing them to admit the crime by the police operatives would be null and void. Accordingly, that statement is slanting.

\section{Aphorism}

Aphorism is a terse statement which expresses a general truth or moral principle. An aphorism can be a memorable summation of the author's point (http://literarydevices.net/rhetoric/;

https://web.cn.edu/kwheeler/resource_rhet.html). In the specimen of this current study, the following aphorisms are used.

A fundamental mantra in criminal law is that it is better for a hundred criminals to go scot-free than for one innocent man to be convicted. Conviction should be decreed when - and only when - the exacting standard of proof beyond reasonable doubt is met.

Absolute certainty of guilt is not demanded by law to convict one of any criminal charge, but moral certainty is required.

The serious procedural lapses committed by the buy-bust team gravely tarnish the credibility of the buy-bust operation and strengthen the defense.

These gaping gaps in the chain of custody of the object of the crime inevitably became fertile patches of ground that allowed reasonable doubt to sprout in the mind of the Court.

The different aphorisms above are the memorable summations of the Court of Appeals' points in reversing the cases appealed to them. Those maxims serve as the supposition of the Court of Appeals' logos or the logical appeals that rely on logic or reason based on reliable evidence of their arguments in acquitting

Journal of English Language Teaching Innovations and Materials (Jeltim), 3(2), 109-130

Copyright () 2021 by the author, e-ISSN 2657-1617 
the accused who were convicted in the different trials or lower courts in Mindanao, Philippines. The Court of Appeals reinforces their arguments through epigrammatic statements which express a general truth or moral principle (http://literarydevices.net/rhetoric/) to change the beliefs of another person (https://web.cn.edu/kwheeler/resource_rhet.html). Those aphorisms swell the audience's emotions within their hearts and minds, for they emphasize the impact of the issue.

With those precepts that the Court of Appeals used in their court decisions, their ethos or the appeal to ethics would be revealed. The use of authority to persuade the audience to believe in their character would be relished. Their ethos makes them credible because without credibility, audiences will doubt their arguments and their decisions to acquit the accused appellants. Using credible sources in their arguments is one method of building credibility and reputation.

\section{Repetition}

Repetition is the use of the same word or phrase for emphasis; when words in speeches are repeated, the brain will likely remember those words (http://facstaff.bloomu.edu/jtomlins/rhetorical_devices.html). The repeated terms below were extracted from the Court decisions of the Court of Appeals in Mindanao.

Conviction should be decreed when - and only when - the exacting standard of proof beyond reasonable doubt is met.

COURT: you said in the previous hearing that you were already abused before you were boxed and you lost consciousness, but in your statement, you said that you were boxed and then you lost consciousness. You did not mention whether you were already abused or not. You clarify, were you already abused before you lost consciousness or were you abused after having been boxed and lost consciousness?

In every case, the overriding consideration is not whether the court doubts the innocence of the accused, but whether it entertains reasonable doubt as to his guilt. Where the pieces of evidence against the accused are insufficient or doubtful to determine the guilt of the accused with moral certainty, he should be acquitted. Speculations, surmises and probabilities cannot take the place of proof beyond reasonable doubt.

Accused-appellant convincingly argued that it is erroneous for the trial court to have used the term splashed in reference to the bloodstains found in accused-appellant's short pants. That was never testified to by witness. He merely said he saw dried bloodstains on the short pants. 
Unfortunately, the prosecution failed to elicit more complete information by asking appropriate follow-up questions. By saying that the bloodstains were splashed on the maong pants, the trial court made a crucial conclusion without any basis in evidence.

In every criminal prosecution, the identity of the offender, like the crime itself, must be established by proof beyond reasonable doubt. Indeed, the first duty of the Prosecution is not to prove the crime but to prove the identity of the criminal, for even if the commission of the crime can be established, there can be no conviction without proof of identity of the criminal beyond reasonable doubt.

It is settled that conviction can be had on the basis of circumstantial evidence provided however that: (1) there is more than one circumstance; (2) the facts from which the inferences are derived are proven; and (3) the combination of all the circumstances is such as to produce a conviction beyond reasonable doubt.

The prosecution has not established probable cause in the arrest of the accused, having no personal knowledge that accused has committed, is committing or about to commit a (sic) selling of shabu being 10 to 15 meters away and could not see the transaction.

Notably, in every prosecution for the illegal sale of prohibited drugs, the presentation of the drug, i.e., as part of the corpus delicti, as evidence in court is also material. Corpus delicti is the body or substance of the crime, and establishes the fact that a crime has actually been committed.

In the Court decisions, the voices of the trial or lower courts, the voices of the accused, the victims, the complainants, their lawyers, the witnesses such as law enforcers, etc., and the voice of the reviewing or appellate court, which is the Court of Appeals in Mindanao, were manifested. Of the stakeholders mentioned, the Court of Appeals voiced out the repeated terms above. Most of the repetitions were used by the Court of Appeals in presenting their reasons for acquitting the accused- appellants and what blunders the trial courts made in convicting the accused-appellants. They repeated the same words or phrases for them to emphasize (http://www.virtualsalt.com/rhetoric.html) their arguments for reversing the cases appealed to them. In doing so, the Court of Appeals showed their discourses and at the same time presented the discourses of the trial or lower courts. Oftentimes, the Court of Appeals exposed the trial courts', the prosecution's, and the witnesses' discourses on the representations of the accused. Through the repetition device used by the Court of Appeals, the trial courts' discourses were revealed, especially in marginalizing the accused. It showed how the social actors like trial courts, prosecutions, law enforcers, etc.

Journal of English Language Teaching Innovations and Materials (Jeltim), 3(2), 109-130

Copyright (C) 2021 by the author, e-ISSN 2657-1617 
enacted their characteristic ways of talking about, and acting with and toward, people and things regarding the cases they were resolving.

\section{Subordinate Clause/Delayed Sentence}

Like all clauses, this word group contains a subject and a verb (plus any accompanying phrases or modifiers) but cannot stand alone. A delayed sentence is a sentence that withholds its main idea until the end (http://facstaff.bloomu.edu/jtomlins/rhetorical_devices.htm). The specimen of this study produced this device.

1. Where the pieces of evidence against the accused are insufficient or doubtful to determine the guilt of the accused with moral certainty, he should be acquitted.

2. If he did not kill his wife, he should have been as bold as a lion to deny it.

3. While the prosecution is correct in saying that the defenses of denial and frame-up are inherently weak, it is well-settled that the conviction of an accused must rely on the strength of the prosecution's evidence and not on the weakness of his defense.

4. When $x x x$ denied having any shabu in his possession, they attempted to load him in a passenger jeepney. When he resisted, xxx punched him on his right shoulder.

5. When he protested, they forced him to admit that he owned the shabu. When he refused, the police officers told him they will file a case against him.

6. When they were on his tricycle, the man gave him something wrapped in a newspaper and told him to hold the same. When appellant refused to obey, the man boxed him, got his wallet, collection box, and the key of his tricycle.

7. While he was handcuffed, the accused noticed that a piece of paper was rubbed in his hands before he was made to enter in the dark room, and to his surprise, there were glowing particles in his hands when he was already in the dark room.

The subordinate clauses in the court decisions were used for narrating the events that happened in each of the cases. They were used in narration mode of discourse, in which the intention is to present an event to the reader: what happened and how it happened. The event itself may be grand or trivial, but whatever it is, the intention is to give the impression of movement in time, to give the sense of witnessing an action (http://www./forms_of_discourse; http://forms-of-discourse-flash-cards/).

Other subordinate clauses in the court decisions above were used in description forms of discourse that tells what things are like according to the five

Journal of English Language Teaching Innovations and Materials (Jeltim), 3(2), 109-130

Copyright () 2021 by the author, e-ISSN 2657-1617 
senses

(Phillips,

https://ww/four-modes-of-discourse;

http:/ / modesdiscterm.htm.). With the use of the subordinate clause device in the court decisions, the description type of discourse made though the description is focused on helping the audience visualize people, places, and events that happened in the cases of this study, but it can also put the audience in a particular mood or create a certain type of atmosphere (http://www.types-ofdiscourse.htm) that happened in the cases under investigation.

\section{Periodic Sentence}

A periodic sentence is a sentence that presents its central meaning in a main clause at the end. This independent clause is preceded by a phrase or clause that cannot stand alone. The effect of a periodic sentence is to add emphasis and structural variety. It is also a much stronger sentence than the loose sentence (https://web.cn.edu/kwheeler/resource_rhet.html). The following are some of the periodic sentences extracted from the court decisions under investigation.

1. In every case, the overriding consideration is not whether the court doubts the innocence of the accused, but whether it entertains reasonable doubt as to his guilt.

2. As frequently stressed in rape cases, the quantum of proof required is one beyond reasonable doubt, to be applied in an exacting measure, for a rape charge is easy to concoct.

3. Given the uncertainty and doubt surrounding the circumstances of this case, the Court is constrained to reverse the conviction of appellant by the trial court.

4. Unfortunately, in this case, the prosecution allegedly failed.

5. Aside from being superficial, Mila's testimony on the identification of the accused significantly differed from the testimony of the other eyewitnesses to the crime.

6. After arriving at the target place, the policemen positioned themselves strategically and watched their civilian poseur buyer transact with accused at the entrance of the latter's residence.

7. In the instant case, accused-appellant contends that the evidence for the prosecution failed to establish the chain of custody of the alleged seized drugs.

8. As a method of authenticating evidence, the chain of custody rule requires that the admission of an exhibit be preceded by evidence sufficient to support a finding that the matter in question is what the proponent claims it to be.

9. At the camp, he was brought to a room where marijuana and money were displayed on the table. 
The rest of the periodic sentences device above made use of prepositional phrases that precede the independent or main clauses that present their central meaning at the end of the sentence to add emphasis and structural variety (https://web.cn.edu/kwheeler/resource_rhet.html). The grammatical features in the periodic sentences device in the court decisions represented and portrayed the social and natural world. They portrayed what happened between and among the people involved in the different cases of this study. They also constructed and effected social relations such as the relations between the law enforcers and the accused, the trial courts and the accused, the prosecution and the accused, the victim and or the complainants and the accused.

According to Allan Luke (http://gseis.edu/faculty/Luke/html), critical discourse analysis focuses on sentence and word-level analysis, drawing analytic methods from systemic functional linguistics, in which Halliday argues that lexical and grammatical features of texts have identifiable functions: they represent and portray the social and natural world, construct and effect social relations, and develop conventions as coherent, identifiable texts in particular media. Written and spoken texts represent particular selective views of the world and set out social relations of 'reading positions' that can interpellate readers, situate and position them in identifiable relations of power and agency in relation to texts.

\section{Passivization}

The use of a passive verb states what has been done, and to whom (https://discourse-analysis/research). The court decisions used the following passivization.

1. He should be acquitted.

2. Accused-appellant's choice to remain silent should not at all be taken against him.

3. Sin-awan was interrogated by Dacara who mauled him when he denied having any shabu in his possession.

4. The identity and integrity of the corpus delicti must definitely be shown to have been preserved with unwavering exactitude.

5. Norilyn was illegally arrested. Second, the evidence, i.e., the marijuana inside the black bag, was not inadvertently discovered.

The passivization showed the power asymmetry between the law enforcers and the accused. With the use of passive voice, in which the one being done of the action is emphasized, the things done by the doer were being narrated spontaneously, for example, "Sin-awan was interrogated by Dacara who mauled him when he denied having any shabu in his possession", showed police brutality and abuse of power among police officers in dealing with their detainees. This forensic discourse showed the injustice of the constables in

Journal of English Language Teaching Innovations and Materials (Jeltim), 3(2), 109-130

Copyright () 2021 by the author, e-ISSN 2657-1617 
interrogating the felons. As a result, the Mindanao Court of Appeals acquitted the accused-appellants' cases appealed to them.

\section{Active Voice}

The use of an active verb gives a clear picture of who performed a particular action and to whom (https://discourse-analysis/research). Active voice is when the subject of the sentence performs the action. Below are the different active voice rhetorical devices employed in the court decisions:

Accused-appellant now asserts that while an accused may be convicted on the basis of circumstantial evidence, still the prosecution must pass the test of moral certainty for the conviction.

The gravity of the offense with its corresponding penalty impels this Court to examine closely the evidence upon which conviction of appellant was based.

The civilian agent then gave the pre-arranged signal to the policemen as planned that the transaction was already consummated and immediately the policemen proceeded to the residence of the accused and caught him at his room.

The court a quo gravely erred in convicting the appellant by relying on the regularity in the performance of public duty by the alleged arresting officers.

One person held his right arm and the other one his left arm.

Appellant claims that the specimens submitted for laboratory examinations were not the marijuana leaves allegedly bought and seized from appellant but fruiting tops.

A policeman took pictures of him with the alleged evidence on the table.

Teun Van Dijk's study entitled Clashes in Beirut After Army Kills Members Of Anti-Assad Group, yields the following results: ... there are instances of active verbs 'kills' and 'shoot', that emphasized who was responsible rather than the sentences being put in the passive (https://discourse-analysis/exampleresearch/CDAanalysis). As with the current study, the court decisions used many active voice constructions devices to emphasize who performed the action. Those active voice constructions employed in the court decisions showed the blunders made by the constables, the prosecutions, and the trial courts. Those devices helped the Mindanao Court of Appeals to unveil the flaws the lower courts arbitrated. 


\section{The Peripheral Rhetorical Devices}

\section{Weaselers}

Weaselers are using qualifying phrases to make a claim plausible or acceptable and to help protect the claim from criticism by watering it down, weakening it and giving the communicator of a claim a way out if the claim is challenged (Alonto, et. Al, 2014). The court decisions as specimens of this research employed only may, may be, and might be, and they are the following.

1. Indeed, an acquittal based on reasonable doubt is in order even if his innocence may be doubted.

2. The trial court may have overlooked a basic Constitutional right of the accused, namely, that no one should be compelled to be a witness against himself.

3. The defense of alibi interposed by the accused may be weak but "A judgment of conviction must be predicated on the strength of the evidence for the prosecution and not on the weakness of the evidence for the defense.

4. Appellant's defense of denial and alibi may be the weakest defense, but it is also fundamental that the prosecution evidence must stand or fall on its own weight and cannot draw strength from the weakness of the defense.

5. It may be true that there are instances where, although a witness may not have actually witnessed the very act of commission of a crime, he may still be able to positively identify an accused as the perpetrator of a crime, these instances however are when the accused is the person or one of the persons last seen with the victim immediately before and right after the commission of the crime.

6. In this case, the circumstances recited by the court a quo might be enough to create some kind of suspicion on the part of the court a quo of accused Carlsen's possible motive, or even involvement.

7. The court a quo tried to argue that one who plans the commission of a crime may be convicted as principal by inducement even if he was not physically present at the crime scene and had no ostensible participation in the crime.

Of all the voices manifested in the court decisions like the trial courts, the prosecutions, the witnesses, the victims and or the complainants, the lawyers, the accused-appellants and the reviewing or appellate court, which is the Mindanao Court of Appeals, the weaselers are seen in the voice of the appellate court. The weaselers rhetorical devices were used as reasons for the appellate court to render their plausible judgment. The weaselers above were used as contrast for the reviewing court to tell their logos because after stating the weaselers, the Court of Appeals stated their reasons that led to the reversal of the cases appealed to them. In the court decisions, the weaselers rhetorical devices really water down the claim, but they help maintain the plausibility of the very argument of the appellate court through the juxtaposition of the claim of the lower court and the claim of the appellate court.

Journal of English Language Teaching Innovations and Materials (Jeltim), 3(2), 109-130

Copyright (C) 2021 by the author, e-ISSN 2657-1617 
Aporia

Aporia is an expression of doubt (often feigned) by which speaker appears uncertain as to what he should think, say, or do (Porter, n.d. www.jrmyprtr.com). In the court decisions examined in this research, there is only one (1) aporia found.

Q: And after the tall slim fellow succeeded in pulling down your panty, what did he do to you?

A: Then he boxed my stomach?

That one aporia above was uttered by a rape victim during crossexamination. That expression of doubt by the rape victim shows that she was uncertain as to what really had happened in the rape case. That aporia was used to reveal the questionable credibility of the rape victim herself. Together with the other inconsistencies and implausibility of the rape victim and the lone witness of that case, the appellate court reversed the lower court decision.

\section{Hypophora}

Hypophora is a rhetorical question that is answered by the speaker or a figure of reasoning in which one or more question/s is/are asked and then answered, often at length, by one and the same speaker, raising and responding to one's own question(s). A common usage is to ask the question at the beginning of a paragraph and then use the paragraph to answer it (http://www.americanrhetoric.com/rhetoricaldevicesinsound.htm). There are only two (2) Hypophoras employed in the twelve court decisions investigated in this study. These are the following:

Could it be that Bueta made the same bargain as petitioner once did, that is, to help identify the other perpetrators in exchange for absolution? We cannot help but ask this question, but hesitate to conjecture on the answer.

Would this lone circumstance, lone evidence be enough to sustain a finding that appellant is guilty beyond reasonable doubt?

We answer in the negative. ....

The two rhetorical questions above which were answered by the speaker, which is the appellate court, were the latter's figure of reasoning on their decisions favorable to the accused-appellants on the cases appealed to them. After the tedious scrutiny of both parties' arguments, the reviewing court raised those questions and responded to them at length. Those questions were asked because the readers already had those ideas on their minds after presenting in the preceding paragraphs the arguments that emphasize the errors (http://www.virtualsalt.com/rhetoric.htm) the lower courts rendered. Those

Journal of English Language Teaching Innovations and Materials (Jeltim), 3(2), 109-130

Copyright () 2021 by the author, e-ISSN 2657-1617 
hypophoras serve as the opening of the executory decisions of the appellate court in which the whole paragraph answers the question raised.

\section{Discursive Devices and their functions}

The discursive devices employed in the production of the Court Decisions are the following: Scene-Setting, Specificity / Indirect Quotes, Blame, Consensus/ Collaboration, Pre-modifiers, Extreme Case Formulations, and Disclaimers.

The Scene-Setting devices provide a mental frame of reference. They set the different scenes or settings or locations of the different crimes and provide the 'starting point' of the cases. They also provide the primary bases for relating what follows the setting. They provide the starting point for the communication, and cohesively anchor the subsequent clauses. The information of each crime or case is placed in a spatial frame making the change of scene or location stand out more sharply and draw extra attention to switches of location, such as from the police station to the crime scene to the police station again, or from the school or from the house to the streets where the crimes were consummated and to the police station, etc. These devices were also used for narration, which is storytelling involving relating a series of events, usually in a chronological order, in which the judge or the jury made efforts in analyzing the merits of each narrative. Scene-Setting was also used for description of the scenes of the crimes in each of the different cases investigated.

Specificity or Indirect Quotes as a discursive device was used to help the audience visualize people, places, and events of the crime scenes. It describes the different scenes of the different crimes explored in this study. It was also used in the exposition of what really happened in the crimes appealed to the Court of Appeals in Mindanao. It was used to place out the information or to expose the events of the crimes to have clear ideas about what happened in a particular crime or case. It was also applied for argumentation in presenting the evidence to elicit logical agreement. The specificity discursive device employed in the court decisions helps in conveying their reasons and evidence in instigating logical concord about the cases appealed to the Mindanao Court of Appeals.

The Blame discursive device was used to pinpoint the errors the trial or the lower courts committed for the accused-appellants to get the justice they seek in the appellate or reviewing court which is the Mindanao Court of Appeals. It expedites the Court of Appeals decisions on the cases appealed to them by revealing the different errors committed in the lower courts either by the trial courts, the prosecutions, and the witnesses. The device is a great help by the Court of Appeals in indicating whether the trial lawyers, during cross-

Journal of English Language Teaching Innovations and Materials (Jeltim), 3(2), 109-130

Copyright (C) 2021 by the author, e-ISSN 2657-1617 
examination, exploit versions of witnesses' narratives observable throughout the texts produced from police interviews.

By means of the blame discursive device, the reviewing court decides whether the lower court's decision is convincing, or not, as when the appellate court favors the appellants, thus reversing the lower court's decision. The reviewing or appellate court sees whether persuasion or conviction is accomplished and if the voices in the lower court are worthy of credence.

The Consensus/Collaboration discursive device is used to strengthen the arguments of the voices in the court decisions, such as the voices of the lower courts, including the trial lawyers, the witnesses, and the accused-appellants, and the voice of the higher court, which is the reviewing or appellate court, the Court of Appeals in Mindanao. Through the consensus / collaboration discourse device, the police officers claimed that they did their normal course of duty because they followed the protocols of their responsibility, which is collaborating with the barangay officials in a buy bust operation in drug cases for example, or cooperating with the other police operatives in the pursuit of the carnappers in a carnapping case, etc. The trial courts argued that they made the right decision because they brought all the accounts involved in the case. But the Appellate Court ruled that the trial courts erred in their decisions by citing discrepancies made by the latter and by mentioning the different jurisprudential factors that correlate with the decisions of the reviewing court in reversing the lower court's decisions on the heinous crime cases appealed to the Court of Appeals in Mindanao.

The pre-modifiers are used to emphasize the ideas on the arguments of the reviewing court on the reversal of their decisions in the heinous crime cases. The pre-modifiers help in pointing out the lapses of the lower courts in their decisions on convicting the accused-appellants of those cases. They are forceful in illuminating the bases of the appellate court in reversing the cases appealed to them by the accused-appellants.

The lexical features of texts used in the court decisions, such as: every, any, no, not, none, not one, no clear, nothing, unfortunately, obviously, absolutely, clearly, for sure, and preliminarily are used as Extreme Case Formulations discursive devices. Those devices represent and portray the social and natural world, or field of both the lower or trial courts and the reviewing or appellate court, the Mindanao Court of Appeals. They disclose the world or the field of the different heinous crime cases. They construct and effect social relations or tenor, for example, between the law enforcers and the accused appellants or between the trial lawyers and the accused appellants, etc. With the extreme case formulations discursive device, the legal language of the court decisions of the heinous crime cases reversed on appeal exhibits clear and understandable

Journal of English Language Teaching Innovations and Materials (Jeltim), 3(2), 109-130

Copyright () 2021 by the author, e-ISSN 2657-1617 
judgments and the reasons, or the logos for why the Court of Appeals overturned the lower courts' decisions.

Disclaimer device was used to demonstrate contrast of the decisions of the reviewing court, the Mindanao Court of Appeals, and the verdicts of the lower courts on the heinous crime cases appealed to the Court of Appeals in Mindanao. The contrast of the judgments is based on the context, which is hinged on the linguistic devices such as; but, except, and unless. In other words, the contrast exists without the fronting of the topic. Fronting the information simply attracts more attention to the change. In a context where contrast exists, creating a frame of reference still draws attention to the switch, for example: left with no choice but to find in favor of Norilyn; nothing else except that; entitled to an acquittal unless; defense of alibi may be weak, but a judgment of conviction; credible witness but must be credible in itself; not to prove the crime but to prove the identity of the criminal; no other recourse but to acquit; guilty must be punished, but only if it is; no man would make any declaration against himself, unless it is true; factual findings of the trial court entitled to the highest degree of respect by an appellate court unless something critical and significant have obviously been ignored or missed; and no other option but to pronounce judgment. Those disclaimers display awareness of potential reception(s) of the utterance prior to opposing it. In this case, the appellate or reviewing court is a mediator of change between the lower or trial courts and the accused-appellants, and the disclaimers are utilized in implementing the change which is the reversal of the cases.

\section{Ideological themes}

This research has two general ideological themes categories. These are the Power Asymmetry and Just to Cast the Blame By the Victim or the Family of the Victim and By the Law Enforcers. Under Power Asymmetry are the following: Unsound Judgment among Trial or Lower Courts; Abuse of Power By the Trial or Lower Court and By the Law Enforcers or Arresting Officers; and Poor as Victims of Injustices. Abuse of power By the Law Enforcers or Arresting Officers includes the following: Immediate Prime Suspect Arrests; Framed Up; Police Brutality; Extortion; Non-Compliance with the Rule on the Chain of Custody; and Non-Preservation of the Integrity of Evidence. In Police Brutality, it comprises the following: Menacing Police Interrogation Procedures and Intimidation.

\section{Postulates Generated}

The following postulates on Forensic Discourse are generated: Prearranged Signal: A Non-Verbal Forensic Discourse; Rule on Chain of Custody: The Mantra of the Drug Crime Discourse; Extrajudicial Oral Confessions Discourse; and The Charge and Solve Discourse.

Journal of English Language Teaching Innovations and Materials (Jeltim), 3(2), 109-130

Copyright () 2021 by the author, e-ISSN 2657-1617 


\section{CONCLUSION}

From the findings of the study, the following implications are being put forward. Contrary to the usual notion that rhetorical devices are not used in the language of law, the current study on Court Discourse yielded many rhetorical devices found on the Court Decisions of the Court of Appeals in Mindanao, therefore, it is inferred from the bulk of the data of this study that rhetorical devices are inevitable in the parlance of law. The rhetorical devices are helpful in showing the blunders made by the constables, the prosecutions, and the trial courts. Those devices helped the Mindanao Court of Appeals to unveil the flaws the lower courts arbitrated. Accordingly, the reviewing court decided the case in favor of the accused-appellants, thus; setting aside and reversing the decisions made by the lower courts against the accused- appellants.

This study disclosed many discursive devices which are used in building the case by presenting the reasons and presenting clearly and orderly the evidence to support the reasons for the arguments regarding the crimes committed by giving the facts, figures, expert testimonies, illustrative examples, or other kinds of evidences that support the thesis of what happened in the crime scenes, either by the different trial or lower courts or the Mindanao Court of Appeals. Hence, this research surmised that the discursive devices are inexorably significant in the Court Discourse. The discursive devices are the building blocks of the arguments in the Court Discourse.

The different ideological themes or patterns exhibited in this study show the abuse of power by the trial courts, law enforcers, arresting officers, police operatives, especially in the warrantless arrest of the alleged drug pusher, the violation of the Chain of Custody in handling drug cases by the police officers such as the no showing and non-preserving of the identity and integrity of the corpus delicti, non-establishment of the identity or participation in the buy bust operation of the one delivering the Request for Laboratory Examination and the non- establishment of the ensuing procedures, and the non-proving of the transaction or sale to have actually taken place etc. This current study proves the Faircloughian concept on the aspects of language and power relationships: behind the language is power in which powerful groups can determine aspects of language and the ways power can work in language. Powerful groups such as law enforcers, trial courts, and prosecutions were behind the language, and their power works in language. This study also concluded that there is imbalanced judgment among trial or lower court decisions that would let the victims suffer if the sentenced accused would not go to the Appellate Court to let their cases be reviewed by the higher court or the Court of Appeals.

\section{REFERENCES}

Alonto, A., et al. (2014). Becoming a critical thinker: a resource book for Philosophy 2

Journal of English Language Teaching Innovations and Materials (Jeltim), 3(2), 109-130

Copyright () 2021 by the author, e-ISSN 2657-1617 
(Argumentation in Contemporary Society). Marawi City, Philippines: Department of Philosophy, CSSH, MSU.

Black, H. (1983). Black's law dictionary. Manila, Philippines: West Publishing Company.

Bitzer, L. (1968). The rhetorical situation. philosophy and rhetoric (2014, November 5). The Free Encyclopedia. Analysis-pdf\#scribd.

Booth, W. (2004). The rhetoric of rhetoric: the quest for effective communication. USA: Blackwell Publishing.

Cotterill, J. (Ed.). (2002). Language in the legal process. New York: Palgrave Macmillan).

Enein, H. (1999). Discourse analysis of legal discourse with reference to Dickens, Cozzens, Kafka, Lee, And Melville. [Unpublished doctoral dissertation]. Ain Shams University.

Fairclough, N. (1995). Critical discourse analysis. London/New York: Longman Publishing.

Luke, A. (n.d.). http://gseis.edu/faculty/Luke/html.

Mueller, F. (2014). Translating management ideas: a discursive devices analysis. UK: Sage Publications.

Olsson, J. Forensic discourse analysis: A work in progress. InHyland, $\mathrm{K}$ and Paltridge, B.(Eds.). (2011). Continuum companion to discourse analysis. New York: Continuum International Publishing Group.

Phillips, (n.d.). Modes of discourse. Proofreadoutloud.

https://sites.google.com/a/proofreadoutloud.com/www/four-modesof-discourse.

Porter, J. (Comp.). (n.d.). Rhetorical devices for speechwriters for the purposes of writing speeches and sharing with you. www.jrmyprtr.com.

Rapp, C. (2010). Aristotle's rhetoric. The Stanford encyclopedia of philosophy.

The People of the Philippines, Plaintiff-Appellee, - Versus - CletoTejero, AccusedAppellant. (2013). Court decisions. www:ca.judiciary.gov.ph. 
Tiersma, P. The Nature of Legal Language. Language and law. http://www.languageandlaw.org/NATURE.HTM].

Unvar, S. and Rahimi, A. (March 2013). A critical discourse analysis of discursive structures in a political text. International journal of science and advanced technology. Volume 3 No 3 (ISSN 2221 8386).

Van Dijk, T. (n.d.). clashes in Beirut after army kills members of anti-assad group. https://discourse-analysis/example-research/CDAanalysis.

Walk, B. (2004). Differences in appellate court case decisions based upon "especially heinous, atrocious, or cruel" statutes. Doctoral dissertation. Alliant International University. https://bit.ly/3vHax7G.

Wodak, R. Critical discourse analysis. In Hyland, K. and Paltridge, B. (Eds.). (2011). Continuum companion to discourse analysis. New York: Continuum International Publishing Group.

Wooffitt, R. (2005). Conversation analysis and discourse analysis: A comparative and critical introduction. London: SAGE Publications.

(1995). The New Lexicon Webster's Dictionary of the English Language. Vol. 1. USA: Lexicon Publications, Inc.

\section{Authors' Brief CV}

Dr. Grace Rafal, Peace Education secretary and chairperson, Graduate Department, MSU, Marawi City was English Department Chairperson. She obtained her PhD Language Studies in MSU and MA Anthropology as Ford Foundation Scholar in Ateneo de Cagayan. She completed academic requirement in MAELT and finished MOOC on Leading Ambitious Teaching and Learning in University of Michigan. 